\title{
From theory to practice
}

As we saw in Part I, the numerous aspiring physicians who studied, like Handsch, at one of the leading Italian or French universities profited from comprehensive training. They not only studied the central, authoritative works of ancient and recent writers in great depth, but they also had various opportunities to acquire the practical knowledge and skill they would need later when diagnosing and treating their patients. Professors even worked specific case histories into their lectures. In Padua, the collegia offered valuable insights into the ways in which the discipline's leading authorities followed a strictly methodical process when identifying pathological changes inside the body and devising treatment. Accompanying their professors during patient visits at the hospital or on house calls brought future physicians face to face with actual patients and witness how the professor interacted with patients of diverse social status.

We know little, however, about how physicians later applied what they had learned in their own practice, how they diagnosed and treated medical conditions in everyday life. Much historical research has focused on the general concepts and theories of learned medicine, on individual elaborations and interpretations of the ideas of leading medical authors and on the lively debates that were sparked by some theoretical questions. ${ }^{1}$ Practical medicine, by contrast, has received much less attention, and the few studies that have been published in this area rely largely on theoretical statements about different illnesses, not on casuistic sources describing everyday practice. ${ }^{2}$

In the first part of this book, we discussed the essential concepts and theories that, with some variation, were taught at universities. At the center of orthodox, Galenic academic medicine was the concept of intemperies or dyscrasia, of an imbalance or disproportion of the four primary qualities (cold, hot, dry, and moist) and/or the four humors (yellow and black bile, blood and phlegm). A therapy that followed this explanatory model consequently needed to aim at evacuating the humor or the two humors that were overabundant and/or to restore the proper relation of the primary qualities. In the case of a hot illness, for example, this would have been done with medicinal plants with a cooling effect. As the familiar, oft

\footnotetext{
1 See the surveys by Bylebyl, Medicine (1985); Siraisi, Avicenna (1987); Siraisi, Medieval \& early Renaissance medicine (1990); Wear, Medicine (1995); Maclean, Logic (2002); Wear/French/Lonie, Medical Renaissance (1985); Cook, Medicine (2006).

2 Wear, Explorations (2000); Maclean, Logic (2002), pp. 234-332; Calabritto, Medicina practica (2006); Siraisi, Medicina practica (2008); on English medicine see Wear, Knowledge (2000); on the fifteenth century, Jacquart, Theory (1990).
}

Ә Open Access. (c) 2022 Michael Stolberg, published by De Gruyter. (c) BY-NC-ND This work is licensed under the Creative Commons Attribution-NonCommercial-NoDerivatives 4.0 International License. https://doi.org/10.1515/9783110733549-005 
reiterated master narrative has it, this orthodox, Galenic medicine widely prevailed during the sixteenth century. It also holds that the radical alternative model was Paracelsism, which had a certain following in the sixteenth century but always remained in a minority position. Until very recently, academic as well as popular historical depictions have thus essentially reduced sixteenth-century medicine to the concept of an imbalance of the humors and qualities in the body, which physicians had to diagnose and equalize. ${ }^{3}$ Even first-rate experts on the learned medical theory of the sixteenth century like Ian Maclean, arrive at the conclusion that the learned physicians of the day ascribed diseases to "asymmetric or unbalanced states of the body". 4

Generalizations such as this disregard one essential question, however: to what degree was the concept of an imbalance of the humors and qualities actually applied in everyday practice? To what degree did it inform the way in which physicians diagnosed and treated their patients? Theory and praxis, as we know, can be worlds apart, not only in medicine. For good reason, Iain M. Lonie cautioned years ago that "without some kind of access to practical medicine and its teaching, we are in danger of ending with a history of medicine which includes everything except the craft of medicine itself." ${ }^{5}$ This reminder remains as relevant as ever and especially when it comes to understanding sixteenth-century medicine. As I have already indicated in my introduction, a detailed study of everyday medical practice reveals profound differences between the concepts that prevailed in the theoretical writing and those that guided the diagnostic and therapeutic practice of physicians: the often-invoked doctrine that illness arose from an imbalance of the humors and qualities in the body proves to have been largely irrelevant in everyday medical practice.

A major reason why historians have largely ignored the marked differences between theory and practice is no doubt that the study of everyday medical practice is attended by great challenges. Theoretical concepts and the debates on them can be studied relatively easily in the numerous medical publications from that time. By contrast, sources for everyday medical practice in the sixteenth century that reflect how physicians applied the theoretical knowledge at the bedside are much more difficult to come by.

3 Jütte, Ärzte (1991), p. 42.

4 Maclean, Logic (2002), p. 260; in addition, Maclean mentions the two other categories which Galen had described but which were irrelevant for most cases of illness physicians encountered in their everyday practice, namely the "mala compositio" of individual organs and the traumatic "solutio continuitatis" (ibid.) which was primarily the domain of surgeons. For an early nuanced account, which focuses more on actual practice see Wear, Popularized ideas (1989).

5 Lonie, Paris Hippocratics (2000), p. 157. 
Among printed sources, published medical case histories offer some important insights at least. Beginning in the middle of the sixteenth century, more and more collections of curationes and medical observationes were published. The genre quickly became very popular among students and physicians. ${ }^{6}$ Like the medical consilia, which met with great interest in the late Middle Ages already, ${ }^{7}$ they gave medical readers an opportunity to learn from the experiences of others and to apply them to their own practice. As a genre, collections medical observationes have garnered some attention in historical research. ${ }^{8}$ So far, however, there are hardly any systematic studies of medical case histories as documents of ordinary medical practice. ${ }^{9}$

To be sure, the problems with this kind of analysis are considerable. It is difficult to draw general conclusions from countless individual cases, especially because many published case histories focus on therapy, on the treatment with various medicines and the respective recipes. Moreover, there is always the question as to whether the published case histories adequately reflect the author's everyday practice - not to mention the everyday practice of most physicians. The authors were mostly very successful and had a large practice. On top of that, they usually made a more or less narrow selection from the numerous cases they had seen. Some limited themselves to publishing observationes rarae to begin with, to extraordinary or unique observations of unusual cases of illness, deformities, and so forth. ${ }^{10}$ Even authors and publishers of collected case histories who asserted that they were presenting cases from the own practice had good reasons to prefer and select those that were complicated and difficult. ${ }^{11}$ Medical readers would not have had much to gain from reports of everyday, banal cases

6 The earliest larger collection of this kind were the Curationes of Amatus Lusitanus; the first centuria appeared in 1551 (Lusitanus, Curationum (1551)).

7 Agrimi and Crisciani, Consilia (1994); see also Lockwood, Benzi (1951); Crisciani, L'individuale (1996).

8 Temkin, Studien (1929); Laín Entralgo, Historia clinica (1961); Stolberg, Formen (2007); Pomata, Sharing cases (2010); eadem, Observation rising (2011); eadem, Word (2011).

9 Huber, Felix Platters "Observationes" (2003); some of my doctoral students in Würzburg and Regensburg have examined how physicians understood and dealt with certain diseases in more detail; cf. Mayer, Verständnis und Darstellung des Skorbuts (2012); Reger, Affectio hypochondriaca (2015); Gößwein, Mater puerorum (2016).

10 Dodoens, Medicinalium observationum (1581); Schenck, Observationum (1600); Hochstetter, Rararum observationum (1624); early examples are the stories of "wondrous" cases and cures of Antonio Benivieni and Girolamo Cardano (Siraisi, L'individuale (1996)).

11 François Valleriola, for example, published 60 case histories, in 1573, and added that he had collected another 600 stories of "more serious" cases. If we add the less serious cases in his practice, his published cases thus clearly represent only a tiny selection of those he had dealt with (Valleriola, Observationum (1573), p. 263). 
and they did not allow the author to show off his extraordinary diagnostic acumen and therapeutic know-how either. For the same reasons admissions of errors and mistakes are few and far between and we find hardly any histories of patients whose treatment ultimately failed or ended with death. ${ }^{12}$ Since they threatened to put the author into a bad light, they were unsuited for publication, although readers could have learned much from the mistakes. Last but not least authors may have embellished stories in order to highlight their skill and success and quite possibly may have invented some of them completely.

Physicians' personal notes and practice journals that were not intended for publication allow for a much better, more realistic view of common medical practice. Unfortunately, very few are extant. My most important source for the following discussion will therefore again be Handsch's notes. In their ability to shed light on everyday medical practice in the sixteenth century, they are unparalleled. In his extensive notes on the numerous cases that he or physicians from his professional environment treated, Handsch frequently included the reasons for the physicians' diagnostic and therapeutic conclusions and decision making. The medical understanding of disease that informed the practice of these physicians becomes especially clear and is most explicit in the hundreds of entries in which Handsch, writing in German, recorded how he and his fellow physicians explained (or could in future explain) medical conditions and the treatments they recommended to patients and their relatives. ${ }^{13}$ I will also draw on other sources, so as to arrive at generalizable statements. The practice journals of Hiob Finzel and Ulrich Lehner will feature prominently here. Detailed explanations about the nature and cause of widespread and common diseases can further be found in handwritten letters which physicians, communicating in the vernacular, sent to patients and their relatives in response to a request for counsel. ${ }^{14}$

12 Unless the responsibility could be attributed to other healers or to the patients themselves; see e.g. Foreest, Observationum (1603-1606), pp. 482-486, on the fatal outcome of various cases of breast cases after they had been treated by empirics.

13 Numerous phrases of this kind can be found in particular in Cod. 11206; for further details see Stolberg, "You have no good blood" (2015).

14 See, in particular, the collection of about 80 consilia by Jacob Horst from the 1570s and 1580s in Staats- und Universitätsbibliothek Göttingen, Ms. Meibom 146. 